\title{
THE SANITARY QUALITY OF TIFTON 85 BERMUDAGRASS AND WRANGLER GRASS HAY STORED UNDER DIFFERENT ENVIRONMENTAL CONDITIONS
}

\author{
VARIAÇÕES DA TEMPERATURA E QUALIDADE SANITÁRIA DE FENO DE CAPIM \\ TIFTON 85 E VAQUERO GRASS SOB DIFERENTES CONDIÇÕES DE \\ ARMAZENAMENTO
}

\author{
Marilda SCHMOELLER ${ }^{1}$; Marcela Abbado NERES' ${ }^{1}$ Sandra Mara STRÖHER'; \\ Newton Tavares Escocard de OLIVEIRA ${ }^{\mathbf{1}}$; Caroline Daiane NATH ${ }^{\mathbf{1}}$; Kácia Carine SCHEIDT ${ }^{\mathbf{2}}$ \\ 1. Universidade Estadual do Oeste do Paraná - UNIOESTE, Mal. Cândido Rondon, PR, Brasil. marildasch@ @otmail.com.br; 2. \\ Universidade Estadual de Maringá, UEM - Maringá, PR, Brasil.
}

\begin{abstract}
This study evaluated the variations in temperature and dry matter content in Tifton 85 bermudagrass and Wrangler grass hay stored under different environmental conditions. The fungal and mycotoxin populations in the hay production area were also evaluated. Fifty samples ( 30 hay bales, ten samples of organic matter [OM], and ten samples of grass [G] before baling) were used in a completely randomized design and factorial scheme with ten treatments (a combination of two classes of G: Tifton 85 bermudagrass and Wrangler grass) and three storage systems: a covered shed without side walls, covered with a clear tarp; an open environment covered with a double-sided tarp; and a ventilated closed shed. Four additional treatments, five replications, and one sample per experimental unit completed the study design. The environment influenced the temperature of the Tifton 85 bermudagrass and Wrangler grass bales, and the dry matter content of the bales during the evaluated period was above the recommended limit $\left(800 \mathrm{~g} \mathrm{~kg}^{-1}\right)$. The genus Penicillium occurred with the highest frequency in the Wrangler grass stored under a double-sided tarp (6.13 $\left.\log \mathrm{CFU} \mathrm{g}^{-1}\right)$. In the additional treatment, the OM deposited in the soil of the Wrangler grass production area exhibited a greater occurrence of the fungus Fusarium (4.66 log CFU g ${ }^{-1}$ ) and of the mycotoxin zearalenone (ZEA; 594.2 $\mu \mathrm{g} \mathrm{kg}^{-1}$ ). The hay stored in the shed with a clear tarp exhibited more aflatoxin (AFLA) and deoxynivalenol (DON). The concentration of mycotoxins varied across the storage environments and between the stored species; however, the shed storage system used in hay production might also be a source of hay contamination via the incorporation of decomposing $\mathrm{OM}$ with mycotoxins in the hay.
\end{abstract}

KEYWORDS: Fungi. Mycotoxins. Roughage

\section{INTRODUCTION}

The use of hay as supplementary roughage has grown in Brazil and worldwide primarily because of the development of machines and implementations that have accelerated the process and minimized losses due to the risk of precipitation. The value of high nutritional quality hay has been recognized because it is a source of physically effective fiber, and it is easy to transport and store. The commercialization of hay has increased recently (NERES et al., 2017); today, it is the main activity of producers who were previously engaged in the production of grain, dairy cattle, and horses.

However, the sanitary quality of preserved roughage has been a cause for concern because of the possibility of contamination via fungi and the possible production of mycotoxins. The sanitary quality of grass $(\mathrm{G})$ hay production can be altered by the procedures adopted for its production and preservation. The proper storage structure of hay is a covered and ventilated shed; however, many producers store their hay in fields or covered with polyethylene plastic tarps. Fungi are present in the developmental environment of $\mathrm{G}$, with the genera Fusarium, Penicillium, and Aspergillus being the major contamination representatives (AMARAL; NUSSIO, 2011).

The present study evaluated the influence of variations in environmental temperature and relative air humidity on the temperature, dry matter content, and sanitary quality of Tifton 85 bermudagrass and Wrangler grass hay under different storage environments.

\section{MATERIAL AND METHODS}

The current experiment was conducted at a hay farm located in Marechal Cândido Rondon, 
Paraná, Brazil, which encompasses a total production area of 20 hectares. The climatic data for the experimental period were obtained from the Meteorological Station of the Experimental Farm in Marechal Cândido Rondon from October 2014 to January 2015. The mean monthly rainfall and temperature (minimum, mean, and maximum) during the storage of Tifton 85 bermudagrass (Cynodon spp.) and Wrangler grass (Cynodon dactylon) hay were calculated.

The Tifton 85 bermudagrass and Wrangler grass were mowed on October 15, 2014, respectively, using a mower conditioner with pivoting steel fingers and a mowing height of $5 \mathrm{~cm}$ above the ground. After mowing, the $\mathrm{G}$ remained in the field for 48 hours to dry to reach the ideal dry matter content for baling (above $800 \mathrm{~g} \mathrm{~kg}^{-1}$ ), with climatic conditions favorable to drying with a maximum temperature of $36.5^{\circ} \mathrm{C}$ on the day of baling.

The bales had a mean weight of $6 \mathrm{~kg}$ and were stored under three different environmental conditions: a ventilated closed shed, an open shed with a clear tarp, and an open environment covered with a double-sided tarp. For all of the systems, the bales were placed on wood pallets with height from the ground of approximately $10 \mathrm{~cm}$, with five bales per pallet, totaling six pallets. The temperatures under the tarp were measured weekly at 1:00 pm (daylight savings time) throughout the experiment, with the aid of a thermometer inserted $10 \mathrm{~cm}$ into the bales and with a laser infrared thermometer.

For the temperature evaluation, 30 hay bales were distributed in a completely randomized design with a split-plot treatment arrangement, with 84 treatments, five replicates, and one bale per experimental unit. The treatments consisted of the combination of two classes of $G$ (Tifton 85 bermudagrass and Wrangler grass) and three classes of storage environments (ventilated closed shed, open shed with a clear tarp, and open environment covered with a double-sided tarp), which were randomized in the plots as well as 14 storage times $(0,7,14,21,28,35,42,49,56,63,70,77,84$, and 91 days) that constituted the subplots.

A completely randomized design with a factorial scheme was used to evaluate the base-ten logarithm of the colony forming unit (CFU) counts of fungi and yeasts and the mycotoxin content of 50 samples (30 hay bales after 90 days of storage, 10 samples of organic matter (OM), and 10 samples of the Gs before baling); 10 treatments, five replications, and one sample per experimental unit were employed. The treatments consisted of the combination of two classes of $G$ (Tifton 85 bermudagrass and Wrangler grass) and three storage system classes (shed, clear tarp, and double-sided tarp) as well as four additional treatments composed of two Gs (Tifton 85 bermudagrass and Wrangler grass) and two OM conditions obtained before baling. Mycotoxins were identified using ELISA (Neogene) at the laboratory Microbiology and Mycotoxicology. The method described by Silva et al. (2007) was used to quantify fungi and yeasts.

The evaluated variables were the weekly temperature $\left({ }^{\circ} \mathrm{C}\right)$ of the hays measured using a laser $\left(\mathrm{T}_{\text {LASER }}\right)$ and spike thermometer $\left(\mathrm{T}_{\mathrm{STICK}}\right)$; the baseten logarithm of the CFU counts of fungi of the genera Cladosporium (LOGCLAD), Fusarium (LOGFUS), Penicillium (LOGPEN), Aspergillus (LOGASP), Rhizopus (LOGRHIZ), yeast (LOGYEA), and total fungi (LOGTOT); and the aflatoxin (AFLA), zearalenone (ZEA), and deoxynivalenol (DON) counts in the Tifton and bermudagrass hay on the 90th day after baling.

The effects of $\mathrm{G}$, storage method (M), and the interaction between $G$ and $M$ on the $T_{\text {LASER }}$ and $\mathrm{T}_{\text {STICK }}$ temperatures were analyzed using a repeatedmeasures univariate analysis of variance (ANOVA). The effects of time and the interactions between time and $\mathrm{G}$, time and $\mathrm{M}$, and the three-way interaction among time, $\mathrm{G}$, and $\mathrm{M}$ on temperatures were analyzed using a multivariate ANOVA (XAVIER; DIAS, 2001).

For $\mathrm{T}_{\text {LASER }}$ and $\mathrm{T}_{\text {STICK, }}$, the following statistical model was used: $\mathrm{Y}_{\mathrm{ijkl}}=\mu+\mathrm{G}_{\mathrm{i}}+\mathrm{M}_{\mathrm{j}}+$ $\mathrm{GM}_{\mathrm{ij}}+\varepsilon_{\mathrm{ijl}}+\mathrm{t}_{\mathrm{k}}+\mathrm{Gt}_{\mathrm{ik}}+\mathrm{Mt}_{\mathrm{jk}}+\mathrm{GMt}_{\mathrm{ijk}}+\varepsilon_{\mathrm{ijk}}$, where $\mathrm{Y}_{\mathrm{ijkl}}$ is the value observed for the response variable in the $\mathrm{i}^{\text {th }} \mathrm{G}$, for the $\mathrm{j}^{\text {th }} \mathrm{M}$, at the $\mathrm{k}^{\text {th }}$ time and at the $\mathrm{l}^{\text {th }}$ replication; $\mu$ is the effect of the overall mean of all observations; $G_{i}$ is the effect of the $i^{\text {th }} G$ for $i=(1$ and 2); $M_{j}$ is the effect of the $j^{\text {th }}$ method for $\mathrm{j}=(1,2$ and 3); $\mathrm{GM}_{\mathrm{ij}}$ is the interaction between $\mathrm{G}$ and method; $\varepsilon_{\mathrm{ijl}}$ is the random plot error due to the interaction between the $\mathrm{i}^{\text {th }} \mathrm{G}$, the $\mathrm{j}^{\text {th }}$ method, and the $1^{\text {th }}$ replication; $t_{k}$ is the effect of $k^{\text {th }}$ time for $j=(1, \ldots$, 14); $\mathrm{Gt}_{\mathrm{ik}}$ is the effect of interaction between $\mathrm{G}$ and time; $\mathrm{Mt}_{\mathrm{jk}}$ is the effect of the interaction between method and time; $\mathrm{GMt}_{\mathrm{ijk}}$ is the effect of the interaction among $\mathrm{G}$, method, and time; and $\varepsilon_{\mathrm{ijkl}}$ is the random error subplot referring to the $\mathrm{i}^{\text {th }} \mathrm{G}$ for the $\mathrm{j}^{\text {th }}$ method at the $\mathrm{k}^{\text {th }}$ time for the $1^{\text {th }}$ replication assuming homoscedastic, independent, and normally distributed data.

After the significance of the interaction between $\mathrm{G}$ and $\mathrm{M}$ was determined by the ANOVA, the means of $\mathrm{G}$, considering each method class, were compared using the F-test. The means between method classes, within each $\mathrm{G}$ class, were compared using the Student-Newman-Keuls test. The effect of 
The sanitary quality of tifton $85 \ldots$

time, for each $\mathrm{G}$ and $\mathrm{M}$ class combination, was evaluated using line graphs, where the behavior of the hay temperature during the experimental weeks could be evaluated.

The degree of association between $T_{\text {LASER }}$ and $\mathrm{T}_{\text {STICK }}$ with regard to the mean, maximum, and minimum environmental characteristics (temperature, relative humidity, dew point temperature, and atmospheric pressure as well as wind speed, gust velocity, radiation, and precipitation) considering each combination of $G$ and $M$ class was tested using Pearson's correlation analysis. A statistical analysis was performed using generalized linear model (GLM) theory to test the characteristics related to the fungus and yeast $\mathrm{CFU}$ counts (in base-ten logarithmic-transformed values) as well as the AFLA, ZEA, and DON counts. The data were fit to normal, Poisson, binomial negative, and gamma distributions (McCULLAGH; NELDER, 1989).

The GLM fit of the characteristic data was performed using an analysis of deviance (ANODE) based on the fit of the maximal model represented by the systematic portion of $\eta=g(\mu)=\mu+G_{i}+M_{j}$ $+\mathrm{GM}_{\mathrm{ij}}+\varepsilon_{\mathrm{ijk}}$, where $\mu$ is the effect of the overall mean, $G_{i}$ is the effect of the $i^{\text {th }} \mathrm{G}$ (i=1 and 2), $M_{j}$ is the effect of the $\mathrm{j}^{\text {th }} \mathrm{M}(\mathrm{j}=1,2,3,4$ and 5$), \mathrm{GM}_{\mathrm{ij}}$ is
SCHMOELLER, M. et al

the interaction effect between the $i^{\text {th }} \mathrm{G}$ and the $\mathrm{j}^{\text {th }} \mathrm{M}$, and $\varepsilon_{\mathrm{ijk}}$ is the random error associated with each observation $\mathrm{Y}_{\mathrm{ijk}}$.

The effects of $G, M$, and interaction between $\mathrm{G}$ and $\mathrm{M}$ were analyzed using a type III analysis in Statistical Analysis System (SAS). After the significance of the model factor was determined via this analysis, the contrasts associated with the differences between least squares means (lsmeans) referring to the effects of $\mathrm{G}, \mathrm{M}$, and $\mathrm{G} * \mathrm{M}$ were compared using the lsmeans difference test via the chi-square statistic. With respect to these results, the means presented were based on the observed values. A 5\% significance level was adopted for all hypothesis tests. The statistical analyses were performed using R and SAS.

\section{RESULTS AND DISCUSSION}

The $\mathrm{G} \times \mathrm{M}$ interaction showed a significant effect $(p<0.05)$ with regard to the TLASER of the hay. However, no significant interaction was found with regard to hay $\mathrm{T}_{\text {STICK }}(\mathrm{p}>0.05)$. We observed that the Tifton hay $\mathrm{T}_{\text {LASER }}\left(29.04^{\circ} \mathrm{C}\right)$ was higher $(\mathrm{p}<$ $0.05)$ than the Wrangler grass $\mathrm{T}_{\text {LASER }}\left(27.44^{\circ} \mathrm{C}\right)$ when the hays were stored using the double-sided tarp method.

Table 1. Means (and standard deviations) of the hay temperature $\left({ }^{\circ} \mathrm{C}\right)$ measured using a laser $\left(\mathrm{T}_{\text {LASER }}\right)$ and a stick $\left(\mathrm{T}_{\text {STICK }}\right)$ thermometer by combinations of $\mathrm{G}$ and $\mathrm{M}$

\begin{tabular}{llll}
\hline G & M & $\mathrm{T}_{\text {LASER }}$ & $\mathrm{T}_{\mathrm{STICK}}$ \\
\hline \multirow{3}{*}{ Tifton 85 } & Shed & $28.41^{\mathrm{aA}}(2.07)$ & $28.34^{\mathrm{bA}}(1.35)$ \\
& Clear tarp & $28.03^{\mathrm{aA}}(2.20)$ & $28.21^{\mathrm{bA}}(1.69)$ \\
& Double-sided tarp & $29.04^{\mathrm{aA}}(3.30)$ & $30.73^{\mathrm{aA}}(2.84)$ \\
\hline \multirow{3}{*}{ Wrangler grass } & Shed & $28.57^{\mathrm{aA}}(2.05)$ & $28.21^{\mathrm{bA}}(1.42)$ \\
& Clear tarp & $27.81^{\mathrm{aA}}(2.22)$ & $28.07^{\mathrm{bA}}(1.66)$ \\
& Double-sided tarp & $27.44^{\mathrm{aB}}(3.11)$ & $30.57^{\mathrm{aA}}(2.94)$ \\
\hline $\mathrm{CV}(\%)$ & 2.43 & 1.63 \\
\hline (1) Means followed by different lowercase letters in the column for the effect of the method, given G (M/G), and by different capital \\
letters in the column for the effect of G, given M (G/M), significantly differed according to the Student-Newman-Keuls and F-tests, \\
respectively, at the 5\% probability level; CV: coefficient of variation; $\mathrm{N}=70$
\end{tabular}

No difference $(\mathrm{p}<0.05)$ was found between the mean $\mathrm{T}_{\text {LASER }}$ of hay stored using the shed, clear tarp, and double-sided tarp methods for either Tifton bermudagrass or Wrangler gass hay. However, the mean $\mathrm{T}_{\text {STICK }}$ of the hay stored using the double-sided tarp method was higher $(\mathrm{p}<0.05)$ than the mean $\mathrm{T}_{\text {STICK }}$ of hay stored using the shed and clear tarp methods for both hays. The $\mathrm{T}_{\text {LASER }}$ measurements were performed on the surface of the hay, and solar radiation might be the main environmental factor that influenced the heating of the hay in the evaluated environments.
Regarding the temperature data of the Tifton 85 bermudagrass hay stored in a shed $(n=70)$, the environmental characteristics that had the strongest association with $\mathrm{T}_{\text {LASER }}$ were mean temperature ( $\mathrm{r}_{\mathrm{XY}}$ $=0.69)$ and mean relative humidity $\left(r_{X Y}=-0.69\right)$. In turn, of all of the environmental characteristics, the mean temperature $\left(\mathrm{t}_{\text {mean }}\right)$ had the strongest correlation with $\mathrm{T}_{\text {STICK }}\left(\mathrm{r}_{\mathrm{XY}}=0.80\right)$. The environmental characteristics that exhibited the strongest association with $\mathrm{T}_{\text {LASER }}$ and $\mathrm{T}_{\mathrm{STICK}}$ were minimum temperature $\left(\mathrm{r}_{\mathrm{XY}}=0.72\right)$ and mean temperature $\left(r_{X Y}=0.83\right)$, respectively, for Tifton $G$ stored with a clear tarp $\left(r_{X Y}=0.79\right)$, and the 
minimum temperature $\left(r_{X Y}=0.70\right)$, respectively, for hay stored with a double-sided tarp.

Regarding the Wrangler grass hay stored in a shed with a clear tarp or a double-sided tarp, the environmental characteristics most strongly correlated with $T_{\text {LASER }}$ were $t_{\text {mean }}\left(r_{X Y}=0.76\right)$, $t_{\text {mean }}$ and $t_{\min }\left(r_{X Y}=0.66\right)$, and $t_{\max }\left(r_{X Y}=0.71\right)$. $T_{\text {STICK }}$ was most strongly correlated with $t_{\text {mean }}\left(r_{X Y}=0.79\right)$, $t_{\text {mean }}\left(r_{X Y}=0.79\right)$, and $t_{\text {mean }}\left(r_{X Y}=0.81\right)$. Hunoff (2015) evaluated bermudagrass hay and observed higher hay temperatures under clear tarp and no tarp conditions, with values above $45^{\circ} \mathrm{C}$ throughout the experimental period. In this study, the highest temperatures observed were $30.73^{\circ} \mathrm{C}$ for the $\mathrm{T}_{\text {STICK }}$ of Tifton hay and $30.57^{\circ} \mathrm{C}$ for that of Wrangler hay, both using the double-sided tarp method (Table 1).

A significant three-way interaction effect ( $p$
SCHMOELLER, M. et al

according to the Wilks' Lambda test within the MANOVA. The behavior of $T_{\text {LASER }}$ over the storage time of Tifton hay in days (Figure 1) showed that the temperature of the double-sided tarp system was closer to the maximum environmental temperature than the clear tarp or shed methods up to 70 days of storage at most points. The maximum temperature was the environmental characteristic that presented the highest degree of association with $\mathrm{T}_{\mathrm{LASER}}$. The correlation between $\mathrm{T}_{\mathrm{LASER}}$ and the maximum temperature for hays stored using the double-sided tarp was $r_{X Y}=0.79$. The main environmental factors that influenced the quality of preserved forage included solar radiation, temperature, relative air humidity, and soil moisture at the time of baling (DOMINGUES, 2009).

$<0.05)$ on $\mathrm{T}_{\text {LASER }}$ and $\mathrm{T}_{\text {STICK }}$ was observed

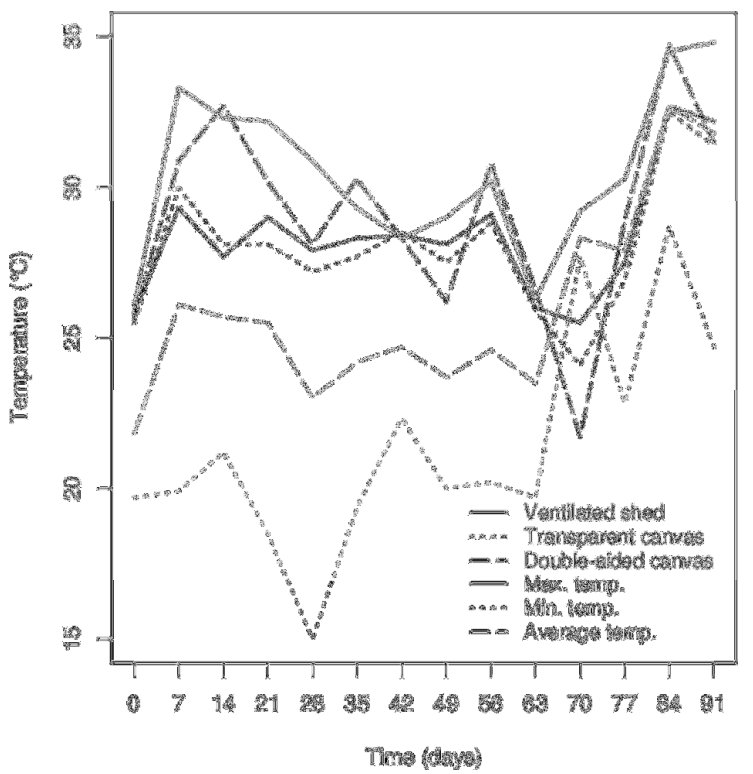

Figure 1. The mean hay temperature measured using a laser thermometer and that of the environmental temperature $\left({ }^{\circ} \mathrm{C}\right)$ of Tifton hay stored under different environments over time (in days)

Ames et al. (2014) monitored the hay temperatures of Tifton $85+$ vetch and of the environment in a shed and observed an increase in temperature until the $14^{\text {th }}$ day after storage because of the high moisture of the vetch forage at the time of baling. Coblentz et al. (2000) stored bales of hay under different densities and moisture contents and observed that nitrogen in Cynodon dactylon is susceptible to reductions in biological availability because of the temperature rises during storage caused by microbiological activity. This heat damage increased as the moisture increased after baling.

The behavior of $\mathrm{T}_{\text {LASER }}$ by the time of storage of bermudagrass hay in days (Figure 2) showed that the temperatures were between the maximum and mean environmental temperatures for the different Ms during the entire storage period.

The environmental temperature, expressed as the mean, minimum, and maximum values, was the characteristic most correlated with the hay temperatures measured using laser and stick thermometers. However, the $\mathrm{T}_{\text {LASER }}$ recorded under the double-sided tarp system did not exceed the mean of $29.4^{\circ} \mathrm{C}$ (Table 1), which is considered normal. The alert phase begins between $49^{\circ} \mathrm{C}$ and $60^{\circ} \mathrm{C}$, whereas a serious risk of spontaneous combustion exists above $70^{\circ} \mathrm{C}$ (MOSER, 1995; McBETH et al., 2001). 


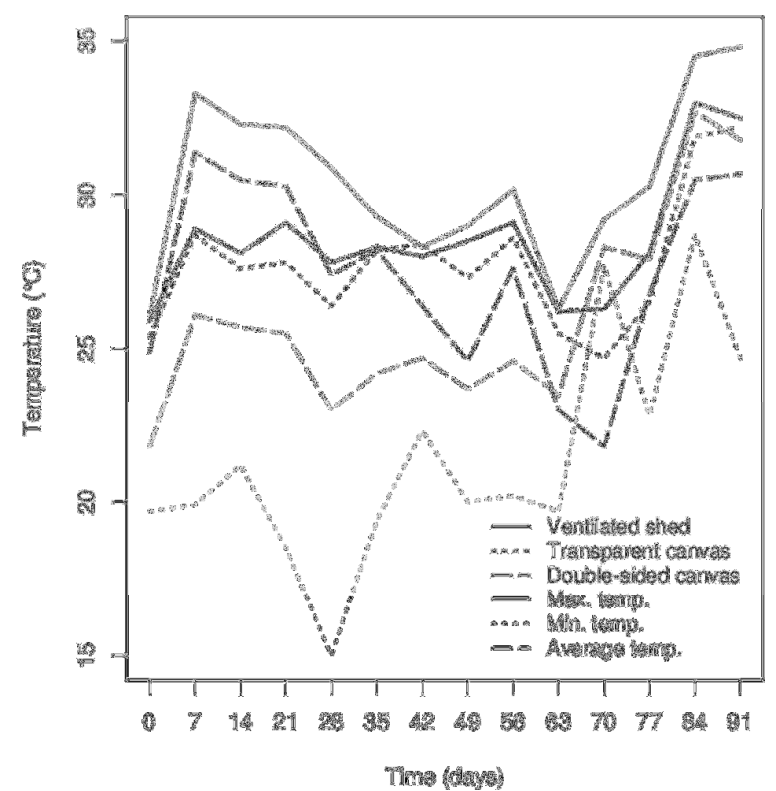

Figure 2. The mean hay temperature measured using a laser thermometer and that of the environmental temperature $\left({ }^{\circ} \mathrm{C}\right)$ of Tifton hay stored using different methods over time (days)

A similar behavior was observed with increasing temperature when the bales were measured using the stick thermometer for Tifton and Wrangler grass hay using the double-sided tarp system after 70 days of storage (Figures 3 and 4).

The temperature of the double-sided tarpstorage system of Tifton 85 bermudagrass $G$ remained below the maximum environmental temperature until 35 days of storage (Figure 3). At 70 days, however, a marked drop in the bale temperature occurred, with values close to $26^{\circ} \mathrm{C}$ and a subsequent considerable increase until the end of storage (above $35^{\circ} \mathrm{C}$ ). This drop in temperature might have occurred because of the climatic conditions of the period prior to sampling, with rainfall occurring every month during the storage period. In October, the cumulative monthly rainfall was $57 \mathrm{~mm}$; in November, December, and January 2015 , the cumulative monthly rainfall was $163 \mathrm{~mm}$, $117 \mathrm{~mm}$, and $168 \mathrm{~mm}$, respectively (Source: Meteorological Station of the Experimental Farm of Unioeste). These data corroborate the behavior of the means observed in Figures 1, 2, 3, and 4.

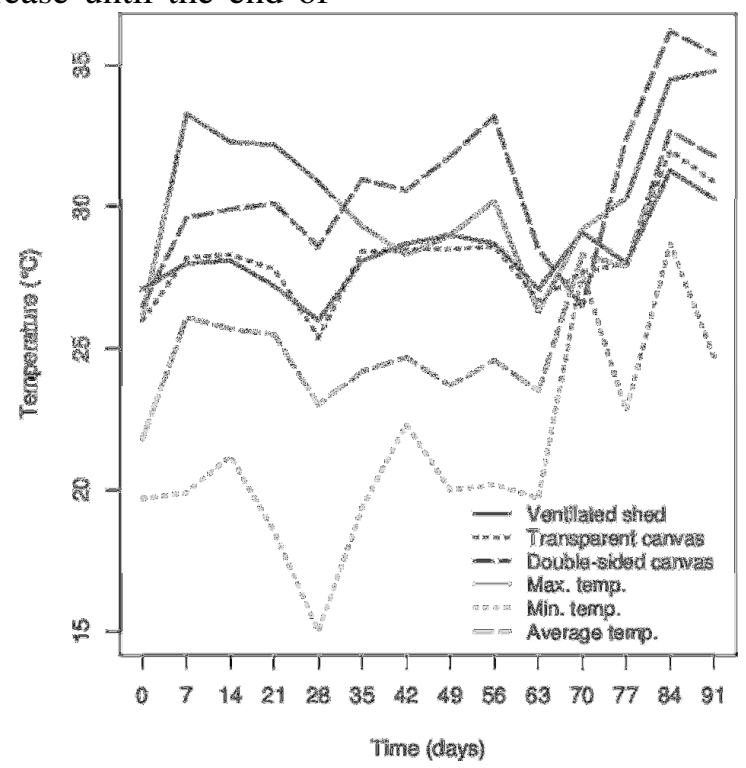

Figure 3. The mean bale temperature measured using a stick thermometer and that of the environmental temperature $\left({ }^{\circ} \mathrm{C}\right)$ in Tifton hay stored using different methods over time (days) 


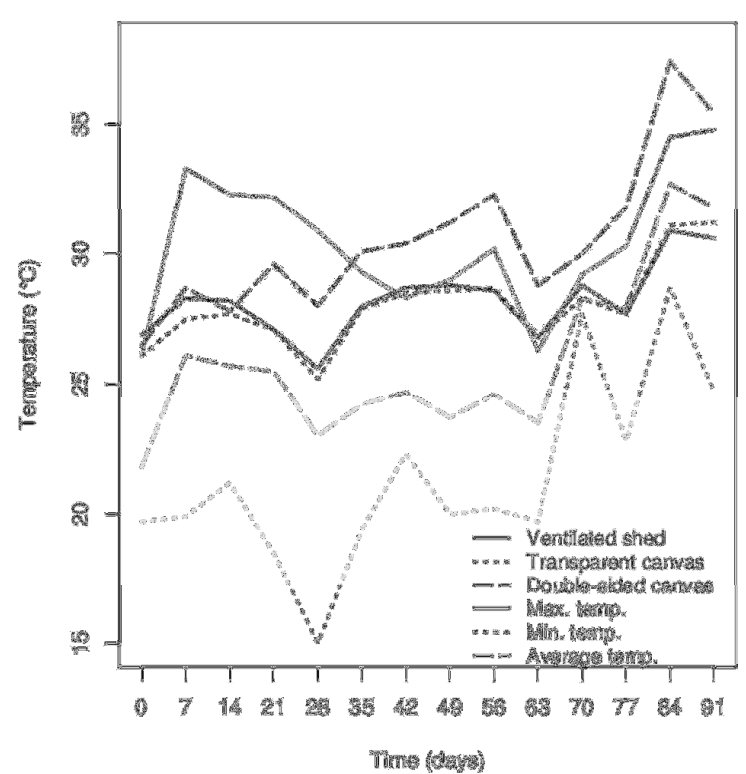

Figure 4. The mean bale temperature measured using a stick thermometer and that of the environmental temperature $\left({ }^{\circ} \mathrm{C}\right)$ in bermudagrass hay stored under different methods over time (days)

High humidity and temperatures above $55^{\circ} \mathrm{C}$ are favorable to the occurrence of nonenzymatic reactions between soluble carbohydrates, resulting in compounds called Maillard reaction products, and nutritional value losses of up to $70 \%$ (VAN SOEST, 1994). In this study, the temperature of the evaluated hay bales was lower than $40^{\circ} \mathrm{C}$; therefore, they were not negatively influenced.

The dry matter content of the Tifton $85 \mathrm{G}$ under different storage environments remained above $800 \mathrm{~g} \mathrm{~kg}^{-1}$ at all storage times analyzed as recommended by Rotz (1995).

A simple effect $(p<0.05)$ of $G$ was observed with regard to LOGCLAD (Table 2). The effect of $G$ was not significant $(p>0.05)$ with regard to the other characteristics.

The mean $\log$ count (CFU g $\mathrm{g}^{-1}$ ) of Cladosporium in Wrangler grass (1.29) was higher $(\mathrm{p}<0.05)$ than the mean LOGCLAD of Tifton 85 hay (0.97; Table 2). These results are consistent with the phenomenon observed by Nascimento et al. (2000), who described the Cladosporium genus as including saprophytic fungi (decomposers of $\mathrm{OM}$ ) that can disappear during storage.

The higher Cladosporium count $\left(\mathrm{CFU} \mathrm{g} \mathrm{g}^{-1}\right)$ in bermudagrass hay compared with the Tifton 85 hay might have been the result of its prostrate and denser leaf architecture, providing adequate conditions for the fungus to develop.

Table 2. Mean log (base ten) individual counts (Cladosporium $s p$ - CLAD; Fusarium $s p$ - FUS; Penicillium $s p$ - PEN; Aspergillus $s p$ - ASP; Rhizopus $s p$ - RHIZ; yeast - YEA) and total fungi and yeasts (TOTAL) found in Tifton 85 and bermudagrass, independent of $\mathrm{M}^{(1)}$

\begin{tabular}{llllllll}
\hline Grass & CLAD & FUS & PEN & ASP & RHIZ & YEA & TOTAL \\
\cline { 2 - 7 } & $---7^{\mathrm{b}}$ & $2.89^{\mathrm{a}}$ & $3.20^{\mathrm{a}}$ & $1.67^{\mathrm{a}}$ & $0.05^{\mathrm{a}}$ & $1.26^{\mathrm{a}}$ & $4.21^{\mathrm{a}}$ \\
\hline Tifton 85 & $0.97^{\mathrm{a}}$ & $2.83^{\mathrm{a}}$ & $1.68^{\mathrm{a}}$ & $0.32^{\mathrm{a}}$ & $0.78^{\mathrm{a}}$ & $4^{\mathrm{a}} 44^{\mathrm{a}}$ \\
Wrangler grass & $1.29^{\mathrm{a}}$ & $2,52^{\mathrm{a}}$ & 74.6 & 100.6 & 317.5 & 150.3 & 29.0 \\
\hline CV $(\%)$ & 133.6 & 59.4 & 74.6 &
\end{tabular}

(1) Means followed by different lowercase letters in the column differ based on chi-square tests at the $5 \%$ probability level; $\mathrm{n}=20 ; \mathrm{p} \geq \chi^{2}$ $($ TOTAL $)=0.0582$

Regarding the variables LOGASP and LOGYEA, a significant difference $(\mathrm{p}<0.05)$ was found only with regard to $\mathrm{M}$, regardless of $\mathrm{G}$ (Table 3). In relation to LOGASP, a higher Aspergillus count $\left(\mathrm{CFU} \mathrm{g}{ }^{-1}\right)$ was observed in the OM collected $(p<0.05)$ compared with the other treatments most likely because conditions more favorable to the fungus (e.g., high moisture content) were present given that growth occurs at humidity levels higher than $15 \%$ (PEREIRA et al., 2002). 
Table 3. Mean log (base ten) individual counts (Cladosporium sp - CLAD; Fusarium sp - FUS; Penicillium $s p$ - PEN; Aspergillus sp - ASP; Rhizopus sp - RHIZ; yeast - YEA) and total fungi and yeasts (TOTAL) according to $\mathrm{M}$, independent of $\mathrm{G}^{(1)}$

\begin{tabular}{|c|c|c|c|c|c|c|c|}
\hline \multirow[t]{2}{*}{ Method } & CLAD & FUS & PEN & ASP & RHIZ & YEA & TOTAL \\
\hline & \multicolumn{7}{|c|}{---------------------------------------'log CFU g } \\
\hline $\mathrm{OM}$ & $2.59^{\mathrm{a}}$ & $4.36^{\mathrm{a}}$ & $2.81^{\mathrm{bc}}$ & $3.86^{\mathrm{a}}$ & $0^{\mathrm{a}}$ & $0^{\mathrm{b}}$ & $2.61^{\mathrm{d}}$ \\
\hline BAL & $1.56^{\mathrm{ab}}$ & $3.57^{\mathrm{ab}}$ & $3.00^{\mathrm{b}}$ & $1.91^{\mathrm{b}}$ & $0.50^{\mathrm{a}}$ & $3.15^{\mathrm{a}}$ & $4.14^{\mathrm{b}}$ \\
\hline S & $0.51^{\mathrm{b}}$ & $2.22^{\mathrm{c}}$ & $2.07^{\mathrm{bc}}$ & $1.42^{\mathrm{b}}$ & $0.44^{\mathrm{a}}$ & $0.87^{\mathrm{b}}$ & $3.30^{\mathrm{c}}$ \\
\hline CT & $0.61^{\mathrm{b}}$ & $2.93^{\mathrm{bc}}$ & $1.07^{\mathrm{c}}$ & $1.20^{\mathrm{bc}}$ & $0^{\mathrm{a}}$ & $0.50^{\mathrm{b}}$ & $3.15^{\mathrm{c}}$ \\
\hline DT & $0.38^{c}$ & $0.41^{\mathrm{d}}$ & $6.13^{\mathrm{a}}$ & $0^{c}$ & $0^{\mathrm{a}}$ & $0.59^{\mathrm{b}}$ & $6.15^{\mathrm{a}}$ \\
\hline $\mathrm{CV}(\%)$ & 133.6 & 59.4 & 74.6 & 100.6 & 317.5 & 150.3 & 29.0 \\
\hline
\end{tabular}

(1) OM: organic matter; BAI: baling; S: shed; CT: clear tarp; DT: double-sided tarp; Means followed by different lowercase letters in the column differ according based on chi-square tests at the $5 \%$ probability level; $\mathrm{n}=8 ; \mathrm{p} \geq \chi^{2}(\mathrm{OMxBAL})$ LOGFUS $=0.0548 ; \mathrm{p} \geq \chi^{2}(\mathrm{CTXDT})$ LOGASP $=$ $0.0530 ; \mathrm{p} \geq \chi^{2}$ (BALXOM; BALXCT; BALXDT)LOGRHIZ $=0.0733$

With regard to LOGYEA, a greater amount of yeasts was found compared with the other treatments, differing significantly from other baling methods (Table 3). The temperature considered ideal for yeast multiplication is between $25^{\circ} \mathrm{C}$ and $30^{\circ} \mathrm{C}$ (CARDOSO, 2006). Yeasts also multiply better when they are in anaerobiosis; however, the fermentative types also develop during aerobiosis (FRANCO; LANDGRAF, 2003).

In general, higher Fusarium sp. counts $\left(\mathrm{CFU} \mathrm{g}{ }^{-1}\right)$ were found in the $\mathrm{OM}$ and at $\mathrm{G}$ baling (Table 3). The fungus Fusarium $s p$. is typically found in field conditions (as stated by Hlodversson and Kaspersson, 1986), which explains their greater occurrence in these materials. None of the factors was significant $(p>0.05)$ with regard to LOGRHIZ, indicating that, regardless of $\mathrm{M}$, the amount of Rhizopus found did not differ (Table 3).

When the interaction between the factors was analyzed, the variables LOGFUS, LOGPEN, and LOGTOT (Table 4) were significant $(\mathrm{p}<0.05)$. Regarding LOGFUS, the analyses of OM and the baling of Tifton $85 \mathrm{G}$ revealed high $(\mathrm{p}<0.05)$ Fusarium growth compared with the other treatments. In bermudagrass, this fungus presented greater development in OM, differing significantly from the others.

Table 4. Mean log (base ten) individual counts (Cladosporium sp - CLAD; Fusarium $s p$ - FUS; Penicillium $s p$ - PEN; Aspergillus sp - ASP; Rhizopus sp - RHIZ; yeast - YEA) and total fungi and yeasts (TOTAL) by the combinations of $\mathrm{G}$ and $\mathrm{M}^{(1)}$

\begin{tabular}{|c|c|c|c|c|c|c|c|c|}
\hline \multirow[b]{2}{*}{ G } & \multirow[t]{2}{*}{ M } & CLAD & FUS & PEN & ASP & RHIZ & YEA & TOTAL \\
\hline & & \multicolumn{7}{|c|}{-------------------------------log CFU g ${ }^{-1}$-------------------------------------- } \\
\hline \multirow{5}{*}{ Tifton 85} & $\mathrm{OM}$ & $1.99^{\mathrm{a} A}$ & $4.06^{\mathrm{a} A}$ & $4.53^{\mathrm{AA}}$ & $3.54^{\mathrm{AA}}$ & $0^{\mathrm{aA}}$ & $0^{\mathrm{cA}}$ & $4.80^{\mathrm{bA}}$ \\
\hline & BAL & $0.87^{\mathrm{aA}}$ & $4.31^{\mathrm{A}}$ & $3.60^{\mathrm{abA}}$ & $2.21^{\mathrm{abA}}$ & $0^{\mathrm{aB}}$ & $2.90^{\mathrm{aA}}$ & $4.67^{\mathrm{bA}}$ \\
\hline & S & $0.65^{\mathrm{aA}}$ & $2.58^{\mathrm{bA}}$ & $1.43^{\mathrm{bcA}}$ & $1.50^{\mathrm{bcA}}$ & $0.25^{\mathrm{AA}}$ & $1.75^{\mathrm{abA}}$ & $2.87^{\mathrm{cB}}$ \\
\hline & $\mathrm{CT}$ & $0.58^{\mathrm{aA}}$ & $2.65^{\mathrm{bA}}$ & $0.71^{\mathrm{cA}}$ & $1.11^{\mathrm{bcA}}$ & $0^{\mathrm{aA}}$ & $0.50^{\mathrm{bcA}}$ & $2.95^{\mathrm{cA}}$ \\
\hline & DT & $0.75^{\mathrm{aA}}$ & $0.83^{\mathrm{cA}}$ & $5.73^{\mathrm{a} A}$ & $0^{\mathrm{cA}}$ & $0^{\mathrm{aA}}$ & $1.18^{\mathrm{bcA}}$ & $5.77^{\mathrm{aA}}$ \\
\hline \multirow{5}{*}{ Wrangler grass } & $\mathrm{OM}$ & $3.20^{\mathrm{A}}$ & $4.66^{\mathrm{a} A}$ & $1.10^{\mathrm{bB}}$ & $4.17^{\mathrm{A}}$ & $0^{\mathrm{bA}}$ & $0^{\mathrm{bA}}$ & $4.94^{\mathrm{bA}}$ \\
\hline & BAL & $2.25^{\mathrm{A}}$ & $2.84^{\mathrm{bcB}}$ & $2.39^{\mathrm{bA}}$ & $1.60^{\mathrm{bA}}$ & $1.00^{\mathrm{aA}}$ & $3.39^{\mathrm{aA}}$ & $3.61^{\mathrm{cB}}$ \\
\hline & S & $0.37^{\mathrm{a}} \mathrm{A}$ & $1.86^{\mathrm{cA}}$ & $2.71^{\mathrm{bA}}$ & $1.35^{\mathrm{bA}}$ & $0.62^{\mathrm{a} B A}$ & $0^{\mathrm{bB}}$ & $3.74^{\mathrm{cA}}$ \\
\hline & $\mathrm{CT}$ & $0.65^{\mathrm{a} A}$ & $3.22^{\mathrm{bA}}$ & $1.43^{\mathrm{bA}}$ & $1.29^{\mathrm{bA}}$ & $0^{\mathrm{bA}}$ & $0.50^{\mathrm{bA}}$ & $3.36^{\mathrm{cA}}$ \\
\hline & DT & $0^{\mathrm{bB}}$ & $0^{\mathrm{dA}}$ & $6.54^{\mathrm{a}} \mathrm{A}$ & $0^{\mathrm{bA}}$ & $0^{\mathrm{bA}}$ & $0^{\mathrm{bA}}$ & $6.54^{\mathrm{a}} \mathrm{A}$ \\
\hline
\end{tabular}

(1) OM: organic matter; BAI: baling; G: shed; CT: clear tarp; DT: double-sided tarp; Means followed by different lowercase letters in the column, for the effect of the method given the $\mathrm{G}(\mathrm{M} / \mathrm{G})$, and different uppercase letters in the column, for the effect of the $\mathrm{G}$ given the method (G/M), differ based on chi-square tests at the $5 \%$ probability level; $p \geq \chi^{2}$ (OMxCT)(LOGCLAD-METHOD/WRANGLER GRASS) $=0.0778 ; p \geq$ $\chi^{2}($ OMxG)(LOGCLAD-METHODWRANGLER GRASS $)=0.0520 ; \mathrm{p} \geq \chi^{2}$ (BALXDT)(LOGASP-METHOD/WRANGLER GRASS $)=0.0675$ 
The genus Fusarium showed a growth predominance, and its requirements are high moisture (greater than 70\%), oxygen, and fluctuating temperatures (hot days and cold nights (AMARAL; NUSSIO, 2011).

According to Zanine et al. (2010), the genus Fusarium is usually found in areas of hay production; however, adequate drying can reduce its population, thereby reducing subsequent losses in the stored hay. Therefore, an adequate drying of the forage before baling might have led to lower $\mathrm{CFU} \mathrm{g}^{-}$ ${ }^{1}$ counts of the genus Fusarium across the different types of hay bale storage in this study.

When evaluating LOGTOT (Table 4), we observed a greater $(\mathrm{p}<0.05)$ amount of fungi and yeast in the samples of Tifton 85 hay under a double-sided tarp compared with those stored in the $\mathrm{OM}$ and at baling, followed by the count of $\mathrm{CFU} \mathrm{g}{ }^{-1}$ of hay stored in the shed and under a clear tarp. In the Wrangler grass hay samples, the LOGTOT of the double-sided tarp treatment was higher $(\mathrm{p}<$ 0.05 ) than that found in the OM samples, followed by the bales stored in the shed under a clear tarp at the time of baling.

The higher total yeast and fungus count associated with the double-sided tarp treatment followed by OM for both Gs observed in this study might be because of the moisture content. The sun's heat added with the foliar transpiration in the double-sided tarp treatment might have led to an accumulation of water droplets under the tarp.

Turner et al. (2002) observed that fungi appeared in these hays under conditions of high moisture, temperature rises and drops in protein availability, demonstrating that all efforts should focus on adequate drying of the material before baling.

The count of the genus Penicillium in the Tifton $85 \mathrm{G}$ was associated with a higher mean LOGPEN $(\mathrm{p}<0.05)$ in the bales of hay stored under the double-sided tarp in the OM and after baling, whereas the samples kept in the shed and under a clear tarp presented with a smaller amount of this fungus. For the bermudagrass, the fungus only showed significant growth in relation to the others using the double-sided tarp method (Table 4).

Mufatto et al. (2016) also concluded that the genus Penicillium had the highest incidence in areas of Tifton $85 \mathrm{G}$ growth destined for the production of hay and fertilized with pig biofertilizer, with a greater population in senescent plant material and soil.

The genera Penicillium and Aspergillus can grow in various types of habitats. These species exhibit optimum development under high temperatures $\left(24-35^{\circ} \mathrm{C}\right)$ and humidity levels above $70 \%$ (MACHADO, 2006). A high population of Penicillium can lead to a greater production of mycotoxins depending on the environmental conditions and species present, and these mycotoxins affect both animal and human health. These results corroborate those obtained by Lacey (1975), who observed a large variety of fungi in dead or senescent material derived from soil and air, growing specifically in native Gs in saprophyte form.

The fungal genera most prevalent in the present study were Penicillium and Fusarium, followed by Aspergillus and Cladosporium. This diversified fungal population is related to the drying process in the field. According to Gregory et al. (1963), a well-diversified population of microorganisms exists during drying in the field, some of it living in the air, plants, and soil. This diversity of propagules suggests that different types of microflora can develop later based on the conditions that can prevail in the bales during any time period.

No effect $(p>0.05)$ of forage species was observed on AFLA (Table 5). Skládanka et al. (2011) also found no effect of the forage species on mycotoxin content, although Festulolium pabulare showed lower ZEA values than other species.

Table 5. Means (and standard deviations) of AFLA, ZEA, and DON according to G, independent of $\mathrm{M}^{(1)}$

\begin{tabular}{llll}
\hline Grass & AFLA $\left(\mu \mathrm{g} \mathrm{kg}{ }^{-1}\right)$ & ZEA $\left(\mu \mathrm{g} \mathrm{kg}^{-1}\right)$ & DON $\left(\mu \mathrm{g} \mathrm{kg}^{-1}\right)$ \\
\hline Tifton 85 & $1.84^{\mathrm{a}}(1.61)$ & $41.3^{\mathrm{b}}(27.4)$ & $0.12^{\mathrm{a}}(0.13)$ \\
Wrangler grass & $1.24^{\mathrm{a}}(1.11)$ & $187.4^{\mathrm{a}}(221.4)$ & $0.07^{\mathrm{b}}(0.09)$ \\
\hline
\end{tabular}

Increases $(\mathrm{p}<0.05)$ in ZEA concentration in bermudagrass and DON in Tifton 85 were observed. AFLA did not differ between species (Table 5). This result is because of the large amount of Fusarium fungus present in the OM collected in the field
(Tables 3 and 4) because it is possible that contamination occurred during the turning of the forage, which is performed with rakes to accelerate the drying of the material. 
With regard to the methods used, the highest concentration of DON was observed in hay stored in the shed. The means found were $0.24 \mu \mathrm{g} / \mathrm{kg}(\mathrm{S})$ and $0.18 \mu \mathrm{g} / \mathrm{kg}$ (CT), and this toxin was not found during bailing (Table 6). In this study, however, the means of the mycotoxin DON were lower than those observed in other studies. For Skládanka et al.
SCHMOELLER, M. et al

(2011), the DON content ranged from 35.07 to $52.78 \mu \mathrm{g} \mathrm{kg}^{-1}$ in the Gs Lolium perenne, Festulolium pabulare, Festulolium braunii, Festuca rubra, and $P o a$ pratensis evaluated during the summer. According to Araújo and Takishita (2007), an intake of $500 \mu \mathrm{g} \mathrm{kg}^{-1}$ or more of DON can decrease milk production.

Table 6. Means and standard deviations (in parentheses) of AFLA, ZEA, and DON according to M, independent of $\mathrm{G}^{(1)}$

\begin{tabular}{llll}
\hline Method & AFLA $\left(\mu \mathrm{gg}^{-1}\right)$ & ZEA $\left(\mu \mathrm{g} \mathrm{kg}{ }^{-1}\right)$ & DON $\left(\mu \mathrm{g} \mathrm{kg}^{-1}\right)$ \\
\hline OM & $0.10^{\mathrm{c}}(0.15)$ & $311.4^{\mathrm{a}}(319.2)$ & $0.013^{\mathrm{c}}(0.04)$ \\
BAL & $0.25^{\mathrm{c}}(0.32)$ & $15.4^{\mathrm{c}}(8.84)$ & $0^{\mathrm{c}}(0)$ \\
S & $2.83^{\mathrm{a}}(0.77)$ & $74.8^{\mathrm{b}}(42.2)$ & $0.24^{\mathrm{a}}(0.07)$ \\
CT & $2.68^{\mathrm{ab}}(1.43)$ & $85.9^{\mathrm{b}}(28.9)$ & $0.18^{\mathrm{b}}(0.07)$ \\
DT & $1.85^{\mathrm{b}}(0.61)$ & $84.2^{\mathrm{b}}(41.1)$ & $0.05^{\mathrm{c}}(0.08)$ \\
\hline
\end{tabular}

(1) OM: organic matter; BAL: baling; S: shed; CT: clear canvas; DT: double-sided tarp; Means followed by different lowercase letters in the column differ based on the results of the lsmeans test at the $5 \%$ probability level; $\mathrm{n}=8 ; \mathrm{p} \geq \chi^{2}$ (BALXDT)(DON) $=0.0603$

A higher concentration $(\mathrm{p}<0.05)$ of ZEA was found in $\mathrm{OM}\left(311.4 \mu \mathrm{g} \mathrm{kg}{ }^{-1}\right)$ compared with the other Ms adopted (Table 6). The interaction between $\mathrm{G}$ and $\mathrm{M}$ on AFLA and DON was not significant ( $\mathrm{p}$ $>0.05)$. However, the interaction between these factors $(\mathrm{p}<0.05)$ on ZEA was significant (Table 7). The mean ZEA values associated with the Tifton 85 hay stored under clear and double-sided tarps were the highest. According to Malmann and Dilkin (2007), fusariotoxins are mostly produced at temperatures between $25^{\circ} \mathrm{C}$ and $35^{\circ} \mathrm{C}$ and humidity above $14 \%$, conditions that are ideal for fungal growth.

The results found in the present study indicated that the use of the double-sided tarp provided a more favorable condition for the growth of Fusarium fungi. The internal mean temperature of the Tifton hay stored with a double-sided tarp $\left(30.73^{\circ} \mathrm{C}\right)$ was higher $(\mathrm{p}<0.05)$ than those obtained using the clear tarp $\left(28.21^{\circ} \mathrm{C}\right)$ and shed $\left(28.34^{\circ} \mathrm{C}\right)$ (Table 1).

Table 7. Means (and standard deviations) of AFLA, ZEA, and DON by the combinations of $\mathrm{G}$ and $\mathrm{M}^{(1)}$

\begin{tabular}{lllll}
\hline $\mathrm{G}$ & $\mathrm{M}$ & $\mathrm{AFLA}\left(\mu \mathrm{g} \mathrm{kg}{ }^{-1}\right)$ & $\mathrm{ZEA}\left(\mu \mathrm{g} \mathrm{kg}^{-1}\right)$ & $\mathrm{DON}\left(\mu \mathrm{g} \mathrm{kg}^{-1}\right)$ \\
\hline \multirow{6}{*}{ Tifton 85} & $\mathrm{OM}$ & $0.10^{\mathrm{cA}}(0.20)$ & $28.6^{\mathrm{cB}}(8.40)$ & $0.025^{\mathrm{bcA}}(0.05)$ \\
& $\mathrm{BAL}$ & $0.25^{\mathrm{cA}}(0.30)$ & $10.8^{\mathrm{dB}}(2.81)$ & $0^{\mathrm{cA}}(0)$ \\
& $\mathrm{S}$ & $3.40^{\mathrm{aA}}(0.65)$ & $39.2^{\mathrm{bcB}}(14.4)$ & $0.28^{\mathrm{aA}}(0.10)$ \\
& $\mathrm{CT}$ & $3.65^{\mathrm{aA}}(0.47)$ & $63.0^{\mathrm{abB}}(9.48)$ & $0.23^{\mathrm{aA}}(0.05)$ \\
& $\mathrm{DT}$ & $1.80^{\mathrm{bA}}(0.78)$ & $64.7^{\mathrm{aB}}(39.7)$ & $0.08^{\mathrm{bA}}(0.10)$ \\
\hline \multirow{4}{*}{ Wrangler grass } & $0.10^{\mathrm{bA}}(0.12)$ & $594.2^{\mathrm{aA}}(156.5)$ & $0^{\mathrm{cA}}(0)$ \\
& $\mathrm{OM}$ & $0.25^{\mathrm{bA}}(0.38)$ & $20.1^{\mathrm{cA}}(10.8)$ & $0^{\mathrm{cA}}(0)$ \\
& $\mathrm{BAL}$ & $2.25^{\mathrm{aA}}(0.30)$ & $110.5^{\mathrm{bA}}(23.6)$ & $0.20^{\mathrm{aB}}(0)$ \\
& $\mathrm{S}$ & $1.70^{\mathrm{aB}}(1.43)$ & $108.8^{\mathrm{bA}}(21.5)$ & $0.13^{\mathrm{bB}}(0.05)$ \\
& $\mathrm{CT}$ & $1.90^{\mathrm{aA}}(0.50)$ & $103.7^{\mathrm{bA}}(36.8)$ & $0.025^{\mathrm{cA}}(0.05)$ \\
\hline
\end{tabular}

(1) OM: organic matter; BAL: baling; S: shed; CT: clear tarp; DT: double-sided tarp; Means followed by different lowercase letters in the column, for the effect of $M$ given $G(M / G)$, and by different uppercase letters in the column for the effect of $G$ given $M(G / M)$, differ based on chi-square tests at the $5 \%$ probability level; $\mathrm{p} \geq \chi^{2}$ (GXCT)(ZEA-METHOD/TIFTON) $=0.0542$

In addition to its temperature, the moisture of the bales stored under the double-sided tarp might have favored the multiplication of fungi because the use of double-sided plastic traps condensation under the tarp (CÂNDIDO et al., 2013). The high temperatures observed close to 90 days of storage (when data collection occurred) contributed to the growth of the mesophilic microorganisms found in the system. 
The OM presented with higher amounts of Fusarium compared with the other genera (Table 7), which corroborates the presence of the large amount of this fungus under the storage conditions.

Importantly, no Fusarium growth was observed in Wrangler grass samples stored under double-sided tarps (Table 5); however, a high incidence of ZEA was observed in the same system (Tables 7 and 8). The presence of fungi in food does not imply that toxins had been produced; on the other hand, the absence of visible signs of mold does not mean that the food was free of toxins because these organisms can persist after the fungi have disappeared (IAMANAKA et al., 2010).

\section{CONCLUSIONS}

The hay bale temperatures of Tifton 85 bermudagrass and Wrangler grass increased as a function of the environmental temperature.

Penicillium was more common in Wrangler grass stored under a double-sided tarp.

The shed and clear tarp conditions showed higher rates of the mycotoxins AFLA and DON. The OM deposited in the soil of the present study was the main source of contamination with Fusarium fungus and the mycotoxin ZEA that it produced, demonstrating the importance of management when curing hay in the field to prevent contamination.

RESUMO: Este estudo teve como objetivo avaliar as variações na temperatura e no teor de matéria seca do feno de capim Tifton 85 e Vaquero armazenados em diferentes condições ambientais. As populações de fungos e micotoxinas na área de produção de feno também foram avaliadas. Cinquenta amostras (30 fardos de feno, dez amostras de matéria orgânica $[\mathrm{OM}]$ e dez amostras de gramíneas [G] antes do enfardamento) foram utilizadas em delineamento inteiramente casualizado e esquema fatorial com dez tratamentos (uma combinação de duas classes de G: Tifton 85 e capim Vaquero) e três sistemas de armazenamento: galpão coberto sem paredes laterais, feno coberto com uma lona transparente; ambiente aberto e o feno coberto com uma lona dupla face; e galpão fechado ventilado. Quatro tratamentos adicionais, cinco repetições e uma amostra por unidade experimental completaram o desenho experimental. $\mathrm{O}$ ambiente influenciou a temperatura dos fardos de Tifton 85 e de capim vaquero, e o teor de matéria seca dos fardos durante o período avaliado foi acima do limite recomendado (800 $\left.\mathrm{g} \mathrm{kg}^{-1}\right)$. O gênero Penicillium ocorreu com maior freqüência no capim Vaquero armazenado sob uma lona de dupla face $\left(6,13 \log _{\mathrm{CFU} \mathrm{g}}{ }^{-1}\right)$. No tratamento adicional, a MO depositada no solo da área de produção de capim Vaquero apresentou maior ocorrência do fungo Fusarium $\left(4,66 \log \mathrm{CFU} \mathrm{g}^{-1}\right)$ e da micotoxina zearalenona (ZEA; 594,2 $\mu \mathrm{g} \mathrm{kg}$-1). O feno armazenado no galpão e coberto com lona transparente apresentou maiores teores de aflatoxina (AFLA) e desoxinivalenol (DON). A concentração de micotoxinas variou entre os ambientes de armazenamento e entre as espécies armazenadas; no entanto, a contaminação do feno pode se dar pela incorporação de $\mathrm{MO}$ com micotoxinas presentes no campo.

PALAVRAS-CHAVES: Fungos. Micotoxinas. Volumosos.

\section{REFERENCES}

AMARAL, R. C.; NUSSIO, L. G. Fungos e micotoxinas. In: SIMPÓSIO: PRODUÇÃO E UTILIZAÇÃO DE FORRAGENS CONSERVADAS, 4., 2011, Maringá. Anais... Maringá: UEM/CCA/DZO, 2011. p. 221-250.

AMES, J. P.; NERES, M. A.; CASTAGNARA, D. D.; MUFATTO, L. M.; DUCATI, C.; JOBIM, C. C; TRES, T. T. Dry matter production, chemical composition, dry matter digestibility and occurrence of fungi in Bermuda grass hay (Cynodon dactylon) under different fertilization systems or associated with pea plantings in winter. Ciencia e Investigación Agraria, Santiago, v. 41, n. 2, p. 163-174, 2014. http://dx.doi.org/10.4067/S0718-16202014000200003.

ARAÚJO, W. A. G.; TAKISHITA, S. S. Micotoxinas presentes nas dietas de animais monogástricos. Revista Eletrônica Nutritime, Viçosa, v. 4, n. 2, p. 405-435, 2007. 
CÂNDIDO, M. J. D.; ANDRADE, I. R. A.; CHAVES, D. R.. Desafios relacionados ao ajuste na taxa de lotação no manejo de pastagens. In: SIMPÓSIO DE FORRAGICULTURA E PASTAGENS, 9., 2013, Lavras. Anais... Lavras: Universidade Federal de Lavras, 2013. 34 p.

CARDOSO, M. G. Produção de aguardente de cana. 2nd ed. Lavras: UFLA, 2006. 445p.

COBLENTZ, W. K.; TURNER, J. E.; SCARBROUGH, D. A.; LESMEISTER, K. E.; JOHNSON, Z. B.; KELLOGG, D. W.; COFFEY, K. P.; MCBETH, L. J.; WEYERS J. S. Storage characteristics and nutritive value changes in bermudagrass hay as affected by moisture content and density of rectangular bales. Crop Science, Madison, v. 40, n. 5, p. 1375-1383, 2000. http://dx.doi.org/10.2135/cropsci2000.4051375x.

DOMINGUES, J. L. Uso de volumosos conservados na alimentação de eqüinos. Revista Brasileira de Zootecnia, Viçosa, v.38, supl., p.259-269, 2009. http://dx.doi.org/10.1590/S1516-35982009001300026.

FRANCO, B. D. G. M.; LANDGRAF, M. Microbiologia dos alimentos. São Paulo: Atheneu, 2003. 182 p.

GREGORY, P. H.; LACEY, M. E.; FESTENSTEIN, G. N.; SKINNER, F. A. Microbial and biochemical changes during the moulding of hay. Journal of General Microbiology, v. 33, n. 1, p. 147-174, 1963. https://doi.org/10.1099/00221287-33-1-147.

HLODVERSSON, R.; KASPERSSON, A. Nutrient losses during deterioration of hay in relation to changes in biochemical composition and microbial growth. Animal Feed Science and Technology, v. 15, n. 2, p. 149165, 1986. https://doi.org/10.1016/0377-8401(86)90022-2.

HUNOFF, Camila Andrine. Composição bromatológica e ocorrência de fungos no armazenamento de feno de capim Vaquero. 2015. 72f. Dissertação (Mestrado em Zootecnia) - Universidade Estadual do Oeste do Paraná, Marechal Cândido Rondon, 2015.

IAMANAKA, B. T.; OLIVEIRA, I. S.; TANIWAKI, M. H. Micotoxinas em Alimentos. Anais da Academia Pernambucana de Ciência Agronômica, Recife, v. 7, p. 138-161, 2010.

LACEY, J. Potential hazards to animal and man from microorganisms in fodder and grain. Transactions of the British Mycological Society Journal, v. 65, n. 2, p. 171-184, 1975. https://doi.org/10.1016/S00071536(75)80001-5

MACHADO, Angélica Patrícia da Silva. Uso de técnicas de detecção rápidas de fungos filamentosos na água. 2006. 64 f. Dissertação (Mestrado em Tecnologia do Ambiente) - Escola de Engenharia da Universidade do Minho, Guimarães, 2006.

MALLMANN, C. A.; DILKIN, P. Micotoxinas e micotoxicoses em suínos. Santa Maria: Palloti, 2007. 238p.

McBETH, L. J.; COFFEY, K. P.; COMBLENTZ, W. K.; TURNER, J. E.; SCARBROUGH, D. A.; BAILEY, C. R..; STIVARIUS, M. R. Impact of heating-degree accumulation during bermudagrass hay storage on nutrient utilization by lambs. Journal of Animal Science, v. 79, n. 10, p. 2698-2703, 2001.

https://doi.org/10.2527/2001.79102698x

McCULLAGH, P.; NELDER, J. A. Generalized linear models. 2nd ed. London: Chapman \& Hall, 1989.

MOSER, L. E. Post-harvest physiological changes in forage plants. In: MOORE, K. J.; KRAL, D. M.; VINEY, M. K. (Eds). Post-harvest physiology and preservation of forages. Madison: American Society of Agronomy Inc., 1995. p. 1-19.

MUFATTO, L. M.; NERES, M. A.; NATH, C. D., STANGARLIN, J. R.; SCHEIDT, K. C.; CASAROTTO, L.; SARTO, J. R. W.; SUNAHARA, S. M. M. Caracterização e quantificação da população de fungos em área de 
produção de feno de capim Tifton 85, adubado com biofertilizante suíno. Ciência Rural, Santa Maria, v. 46, n. 3, p. 486-491, 2016. http://dx.doi.org/10.1590/0103-8478cr20150467.

NASCIMENTO, J. M.; COSTA, C.; SILVEIRA, A. C.; ARRIGONI, M. B. Influência do método de fenação e tempo de armazenamento sobre a composição bromatológica e ocorrência de fungos no feno de alfafa (Medicago sativa, L. cv. Flórida 77). Revista Brasileira de Zootecnia, Viçosa, v. 29, n. 3, p. 669-677, 2000. http://dx.doi.org/10.1590/S1516-35982000000300005.

NERES, Marcela Abbado; NATH, Caroline Daiane; SUNAHARA, Samantha Mariana Monteiro. Cenário da produção e comercialização de feno e pré-secagem no Brasil. In: SIMPÓSIO: PRODUÇÃO E UTILIZAÇÃO DE FORRAGENS CONSERVADAS, 6., 2007, Maringá. Anais... Maringá: UEM, 2017. p. 141-170

PEREIRA, M. M. G.; CARVALHO, E. P.; PRADO, G. Crescimento e produção de aflatoxinas por Aspergillus flavus e Aspergillus parasiticus. Boletim do Centro de Pesquisa de Processamento de Alimentos, Curitiba, v. 20, n. 1, p. 141-156, 2002. http://dx.doi.org/10.5380/cep.v20i1.1143

ROTZ, C. A. Field curing of forage. In: MOORE, K. J.; KRAL, D. M.; VINEY, M. K. (Eds). Post-harvest physiology and preservation of forages. Madison: American Society of Agronomy Inc., 1995. p. 39-66.

SILVA, N.; JUNQUEIRA, V. C. A.; SILVEIRA, N. F. A.; TANIWAKI, M. H.; SANTOS, R. F. S.; GOMES, R. A. R.; OKAZAKI, M. M. Manual de métodos de análise microbiológica de alimentos. 3rd ed. São Paulo: Varela, 2007. 536p.

SKLÁDANKA, J.; NEDĚLNÍK, J.; ADAM, V.; DOLEŽAL, P.; MORAVCOVÁ, H.; DOHNAL, V. Forage as a Primary Source of Mycotoxins in Animal Diets. International Journal Environment Research Public Health, v. 8, n. 1, p. 37-50, 2011. http://dx.doi.org/10.3390/ijerph8010037.

TURNER, J. E.; COBLENTZ, W. K.; SCARBROUGH, D. A.; COFFEY, K. Changes in nutritive value of bermudagrass hay during storage. Agronomy Journal, v. 94, n. 1, p. 109-117, 2002. http://dx.doi.org/ 10.2134/agronj2002.0109.

VAN SOEST, P. J. Nutritional ecology of the ruminant. 2nd ed. New York: Cornell University Press, 1994. 476p.

XAVIER, L. H.; DIAS, C. T. S. Acurácia do modelo univariado para análise de medidas repetidas por simulação multidimensional. Scientia Agricola, Piracicaba, v. 58, n. 2, p. 241-250, 2001. http://dx.doi.org/10.1590/S0103-90162001000200005.

ZANINE, A. M.; SANTOS, E. M.; DANTAS. P. A. S.; SILVA, T. C., DÓREA, J. R. R; FERREIRA. D. J.; OLIVEIRA, J. S. Populações de fungos, leveduras e composição bromatológica do feno de capim Tanzânia tratado com cal (CaO). Livestock Research for Rural Development, v. 22, n. 11, p. 1-8, 2010. 